\title{
Optimization of Public Services of State Civil Services in Human Resource Management Perspective in Poso Regional Public Hospital (RSUD)
}

\author{
Suwardhi Pantih ${ }^{1}$, Syahir Natsir ${ }^{2}$, Idris $^{3}$, Harnida Wahyuni Adda ${ }^{4}$ \\ ${ }^{1}$ Sintuwu Maroso University, Indonesia \\ ${ }^{2,3,4}$ Tadulako University, Indonesia \\ spantih@yahoo.com
}

\begin{abstract}
This study aims to determine the optimization of public services for the State Civil Apparatus (ASN) from the perspective of human resource management and the supporting and inhibiting factors in the Poso Regional General Hospital. This type of research is qualitative research. The results showed that transparency is open, easy to understand and accessible to all parties who need it and is provided adequately and easily understood. This dimension is felt by the community who uses the service as good, so the community evaluates it well and feels the satisfaction of the services provided. Transparency affects the service process in order to create a good impression so that the ultimate goal of satisfaction can be achieved. This dimension of accountability is the ability to provide services in a timely and consistent manner, service standards and promised times that can be accounted for. Conditional, namely the responsiveness of the apparatus in providing the services needed and being able to complete the service quickly according to the promised time period with the conditions and capabilities of the service provided by the officer. This condition situation is related to the reason and way of thinking of the apparatus shown to the customer. Participation encourages community participation in service delivery by taking into account the aspirations, needs and expectations of the community. The guarantee dimension includes knowledge, ability, politeness and trustworthiness possessed by the apparatus, free from dangers, risks, and doubts that result in disturbances in the normal structure of life. Providers and recipients of public services must fulfill the rights and obligations of each party. The inhibiting factor is the lack of apparatus resources, the lack of infrastructure and infrastructure. The supporting factors are encouraging each other's apparatus, holding coordination or evaluation meetings every three months and then giving the planting of awareness to serve the community sincerely and according to conscience.
\end{abstract}

Keywords optimization; service; management

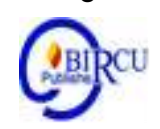

\section{Introduction}

According to Bill Christian, Marlian Tineke and Joseph Kurniawan (2017) state that the poor performance of public services is partly due to the lack of accountability in the delivery of public services. Therefore, public services must be carried out in a transparent and accountable manner by every service unit of government agencies because the quality of the performance of the public service bureaucracy does not have broad implications in achieving public welfare. Accountable and transparent public service is to provide 
excellent service to the community in accordance with the needs in administrative needs, with maximum service work procedures and mechanisms, which are supported by facilities, facilities and infrastructure. So that the services provided are of high quality for the community because they are in accordance with the principle of service.

Public services provided by government agencies have not been able to meet the quality expected by the community. The realities that occur in the Regional General Hospital (RSUD) Poso are the complaints of the public regarding basic services. Such as inpatient management, handling of patient diagnoses, treatment cards, taking drugs that take a long time due to the limited number of pharmacy staff and inaccurate handling of medical actions. In addition, another complaint is the uncertainty of time which results in low quality of service. Time uncertainty can create a bad image for these government agencies. Considering that the main function of the government is to serve the community, the government needs to continue to strive to improve service quality.

Government in improving public services, with complaints and complaints that are incidental. This complaint also drastically increased on systemic problems in policies that resulted in protracted delays, illegal fees, uncertainty in service procedures and conflicts of interest. The lower the implementation of public services, can trigger an increase in the potential for illegal fees and it can be judged that public service agencies have ignored the law.

The Poso Regional General Hospital (RSUD) is one of the government agencies that provides public services. This hospital serves as a public service provider with the main task of assisting the Regent in administering governance, development and society in the Poso Regency area and increasing the effectiveness of public services in the context of good governance and improving the quality of services in the form of services through transparency and service standardization. Good service to the community must be supported by a civil apparatus who is reliable, competent, capable of understanding and able to carry out its main duties and functions in accordance with the area of responsibility assigned to it. In addition, they certainly must have a moral commitment and responsibility to society. The community certainly wants to get a good quality service from the government.

Based on this, a phenomenon related to public services was found. Problems related to public services, namely regarding the length of service that is hampered due to inappropriate directions, officials who do not perform their duties optimally and services that are not friendly to patients From the observations, it shows that the counter part lacks officers as a public service. This happens two or three times each day. The absence of this officer causes service users to have to wait and even the services are carried out by other employees. In addition, officers have the duty to notify the flow or process of service users' needs, which is always absent.

\section{Review of Literatures}

Human resources are integrated capabilities of the mind and physical power possessed by individuals. Human resources are seen as capabilities possessed by humans to be utilized to run an organization or business so that it is efficient or successful (Werdhiastutie, 2020). Human resource development is an effort to develop the quality or ability of human resources through the process of planning education, training and management of personnel or employees to achieve an optimal result (Notoatmodjo in Sulasmi, 2020). 
Human resource management is very important for hospital agencies in managing, managing and utilizing its employees so that they can function actively to achieve the expected goals. Kusdyah (2008) states: to realize the goals of an organization effectively and efficiently, Human Resources must be defined not by what Human Resources do, but what Human Resources produce.

Human resource management is an effort to direct and manage human resources in an organization so that they are able to think and act as expected by the organization. Human Resource Management is management that focuses its attention on employees or personnel in an organization. An advanced organization is certainly produced by employees who can manage the organization towards the progress desired by the organization, on the other hand, not a few organizations are destroyed and fail due to the inability to cultivate their human resources.

Human Resource Management is the science and art of managing the relationships and roles of the workforce in order to be effective and efficient in helping to achieve the goals to be achieved. Humans need organization and on the other hand, organizations also need humans as the driving force, without humans organizations do not function. Likewise, the psychological potential of an employee in carrying out his job is abstract and has no clear boundaries. According to S.S Khanka (2003) simply, Human Resource Management is a process to make someone more efficient and effective in developing human resources so as to achieve the expected goals. Having quality human resources cannot just happen, it takes time to form reliable Human Resources who are ready to achieve their goals.

Michael Armstrong (2009) Human Resource Management is an integrated strategy and is able to have an impact in an organization through positive relationships and influence for the organization itself. According to William B, Jr. and Keith Davis (1993), Human Resource Management is a human resources department obtains, develops, utilizes, evaluates, maintains, and retains the right numbers and types of workers to provide and approve the work force.

It can be concluded that Human Resource Management is a series of recruitment, development, maintenance and management activities that specifically regulate the use of professionally managed human resources to achieve individual and organizational goals in a programmed and integrated manner in order to produce productive and productive human resources. quality and have a high work ethic and loyalty. According to Flippo (Handoko, 2000) that personnel management is planning, organizing, directing and controlling labor procurement, development, compensation, integration, maintenance, and termination of employment with human resources to achieve the organization.

Human Resource Management is a matter of staffing and personnel in an organization, which includes job analysis, recruitment, selection of prospective workers, orientation, training, rewarding, assessment and development of Human Resources. Aspects of management and Human Resources are so strategic and so broad, Human Resource Management involves many aspects, especially with the factors of the organization's internal environment (strengths and weaknesses) and the external environment (opportunities and threats).

According to Priyono (2010), Human Resource Management is the process of obtaining, training, assessing and providing compensation to employees, paying attention to their work relationships, health, safety and justice. HRM also focuses on planning, organizing, directing and controlling the procurement, development, compensation, integration and maintenance of the workforce with a view to helping achieve organizational, individual and community goals. 
Optimizing public services according to the opinion of Indri and Hayat (2005), namely providing professional and quality services that have positive implications for community satisfaction. Service professionalism is supported by attitudes and behavior in service delivery. Human resources are an important indicator in public services. The existence of apparatus resources is the main element in service delivery. The bureaucracy is the main actor in direct contact with the community as service recipients. Quality services depend on various aspects, including appropriate and quality human resources and institutions (Ismail: 2009). State apparatus is the key to the success of public services in government agencies or institutions. If the apparatus is competent, then the service can be carried out properly, of course the quality of the service provided also affects the aspects it serves. Namely, the quality of public services is determined by who provides the service.

Indri and Hidayat (2015) state that the optimization of public services in providing professional and quality services has positive implications for community satisfaction. Optimization of public services in the perspective of Human Resource Management is an act of service provided by the apparatus through six principles of public service that is carried out professionally with an attitude and behavior that is full of responsibility so as to provide maximum and measurable results. Maximum service will provide satisfaction for service users so that it can be said of quality service. Quality services will increase the number of service users.

\section{Research Methods}

Judging from the type of data, the research approach used in this study is a qualitative approach, namely research that intends to understand the phenomenon of what is experienced by research subjects holistically, and by means of descriptions in the form of words and language, in a special natural context. and by utilizing various scientific methods (Moleong, 2007: 6).

Research on Optimization of Public Service for State Civil Servants in the Perspective of Human Resource Management at the Poso Regional General Hospital was conducted using qualitative research, to solve phenomena that occur in the form of written words or explanations after going through observations of people's behavior as data. The intended data is in the form of interview manuscripts, field notes, photos, videos, and documents related to services. The object of this research is focused on the apparatus, namely officers and medical personnel at the Poso Regional General Hospital (RSUD). The research subject is the community as patients or service users. In carrying out this research, primary data collection and collection techniques are in accordance with qualitative research, using the following methods: observation methods, in-depth interviews, documentation and Focus Group Discussion.

\section{Discussion}

Optimization of Public Service for State Civil Servants in the Perspective of Human Resource Management in Poso Regional General Hospital (RSUD) is measured by the quality of service actions using the principle of public service based on the Decree of the Minister of State Apparatus Empowerment Number 63 of 2003, namely Transparency, Accountability, Conditional, Participatory, Equal rights, balance of rights and obligations; then added with wholehearted service based on the theory of Patricia Patton (1999). These seven principles are used as the basis for evaluating service optimization as seen by the quality of service actions, as in the following description: 
Transparency: services provide access and facilities to obtain information for service users to make it easier and more focused in carrying out a series of services, provide detailed and accurate information needed by service users or patients, perform service actions in accordance with work standardization and provide facilities that ensure comfort for service users or patients as well as improving existing facilities and facilities.

Accountability: employees and medical personnel as service providers must be more thorough and careful in obtaining information when handling each service user or patient so that it is more focused and detailed to diagnose, there is an increase in professionalism in accordance with the work field so that it is effective in providing services and increasing expertise and skills for more proficient in operating the technology of all media, facilities or tools in optimizing service actions for more efficient and quality services.

Conditional: employees and medical personnel know well the needs of service users or patients so that they respond through communication relationships that are built based on a sense of empathy and responsibility to meet the patient's needs, always be alert in their respective work units so as to anticipate and provide fast and appropriate actions address any complaints and needs of service users or patients and are willing to accept input and suggestions delivered either directly or indirectly (preparing a suggestion box or evaluation form to determine the effectiveness of the services provided) as a basis for improvement for higher quality services.

Participatory: service users or patients receive guarantees of timeliness starting from administrative arrangements or completeness of letters, getting a diagnosis from a doctor's examination, getting the right action and treatment and other service actions according to the needs of the service user or patient. In addition, it provides a transparent fee guarantee in accordance with the service action provided and receives the right of the action that has been given to service users or patients. But it also adjusts to the health insurance or insurance that the patient follows, so that payments are made in accordance with the measures given.

Equal Rights: providing services with a friendly and polite attitude, an attitude of indifference when serving means that employees and the medical team do not prioritize service users who already know, such as family or close friends. All must be served equally and must match the queue number. Then, an attitude of appreciation can be done by greeting and smiling with service users, asking and recording customer needs, providing explanations related to customer needs, and trying to meet customer needs.

Balance of Rights and Obligations: health services already provide facilities and service measures in accordance with quality service standards. Starting from the equipment that is continuously updated, comfortable rooms, adequate facilities, modern medical equipment, service measures from medical personnel and doctors; comfortable and safe environment; and providing a nutritious diet. This requires that patients as service users, with quality and feel satisfied for complete health services, consciously carry out their obligations to complete administration and make payments according to the health services demanded.

Wholehearted Service: being creative and self-motivating is an integral part of taking action in the health sector so that it can handle managing emotions and solving difficult problems that are found. Creative is building appreciation and creativity with thoughts and ideas that exist within the apparatus when encountering challenges, problems, so that they can arrange, design, and act to provide solutions to solve problems faced in providing good service actions for users service. Self-motivation, namely being able to generate enthusiasm from within, think positively and optimistically, when the apparatus experiences despair and is unable to solve the problems faced while providing services. 
This integrated ability will be able to make the apparatus survive and control themselves from the problems at hand.

Meporioko ri Kabuyandaya is a whole-hearted service which is an act of service provided on the basis of having a sense of self-confidence, enjoying work, having emotional abilities, good character in interacting with service users. Wholehearted service is carried out on the basis of understanding correctly what is the problem of service users, so that they can provide maximum service and resolve user complaints. Because it has good character values, the internalization of these values in service actions will also be well received by service users. The acceptance of good service by service users makes quality service. The concept of wholehearted service is very influential in providing health services for service users.

The obstacles to health services at the Poso Regional General Hospital (RSUD) are first, the number of patients and the public who do not know about health information at the hospital so that many complaints come in, starting from the length of service to information about unclear services. In the implementation of the Health Service Information System, initially it ran smoothly, many obstacles were faced in using the service information system. Human resource problems in the mastery of Information Technology (IT) are the main obstacles in the use of this information system, this results in less than the expected results at the beginning of the application of this information system.

Second, it still does not have adequate human resources to provide health services for all patients. The number of medical personnel owned by the Poso Regional General Hospital (RSUD) is still lacking in the doctor's department, this is considered insufficient to serve existing patients. The hospital still lacks doctors in specialist and sub-specialist fields. Additional medical personnel are still being made

Third, the existing facilities and infrastructure do not match the type or quantity. For example, such as inpatient rooms, waiting facilities for patient families and other facilities and infrastructure. The service environment does not provide a sense of comfort for patients and their families, especially aspects of cleanliness, tranquility, security and comfort.

\section{Conclusion}

Based on the results of the study, it can be concluded that the quality of health services at the Poso Regional General Hospital (RSUD) is based on the principles of public service according to regulations, namely transparency, accountability, conditionality, participation, equality of rights and balance of rights and obligations, service has fulfilled all these principles optimal except on the conditional principle. To fulfill the principles according to the existing regulations and be able to run optimally, it is necessary to add the principle of wholehearted service. This hospital has provided services that are open and reach all communities without discriminating against status backgrounds, as well as involving the community by holding health education and discussions.

Meanwhile, according to the conditional principle, the health service in this hospital is very suboptimal, the problem of resource constraints, the inadequate health facilities make the hospital unable to meet the needs. In addition, health services for patients using BPJS or other similar programs are implemented properly, but there are still many problems regarding the service that are not satisfactory. The main obstacle in health services at this hospital is the insufficient human resources, especially specialist doctors, and the lack of infrastructure to meet the needs of special patients, there are still missing facilities. 


\section{References}

Amstrong, Michael, 1990, Human Resource Management Management Guidelines Series, (Translated: Sofyan and Haryanto), Jakarta: Elex Media Komputindo Gramedia Group.

Bill CR, et al. 2017. Accountability of Apparatus Performance in Public Services Sendangan Village, Kawangkoan District. Executive Journal, 1 (1). https: // ejournal. unsrat.ac.id/index.php/jurnaleksaksana/article/view/15521

Handoko Hani. T. 2016, Management, Issue 2, BPFE, Yogyakarta

Kusdyah, 2008, Human Resource Management, Yogyakarta, CV. Andi Offsite.

Patton, Patricia, 1998, Wholehearted Service IQ, Received EQ for Service, Service With Emotional Quotient, Jakarta.

Priyono, 2010, Human Resource Management. Jakarta

S.S. Khanka, 2003, Human Resource Management. Revised Edition, Seventh Printing, Earth Literacy. Jakarta.

Sulasmi, E. (2020). The Development Strategy of Human Resources Management In Children's Social Welfare Institution (LKSA) (Case Study in LKSA AL-Mubaraak Orphanage Bengkulu). Budapest International Research and Critics Institute-Journal (BIRCI-Journal). P. 562-569.

Werdhiastutie, A., et al. (2020). Achievement Motivation as Antecedents of Quality Improvement of Organizational Human Resources. Budapest International Research and Critics Institute-Journal (BIRCI-Journal). P. 747-752. 